\title{
Editorials
}

Richard I. Cook MD

\section{Syringe pump assemblies and the natural history of clinical technology}

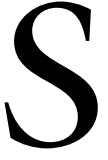

YRINGE pump assemblies - the combination of a driving mechanism, a syringe, length of tubing, and a three-way stopcock - appear straightforward, easy to understand, and simple to use. These assemblies are used to provide continuous infusions in intensive care, infusions that may be continued over long periods that include trips to and from the operating room. Continuous infusions of vasopressors are adjusted empirically to strike a balance (frequently a precarious one) between competing physiological forces. The precise rate of infusion often reflects a carefully chosen tradeoff point between conflicting goals. Once established, interrupting an established infusion can have grave consequences.

Experienced practitioners take care to avoid maneuvres that might change the flow rate of vasoactive drugs to patients. Yet, problems continue to dog the use of syringe pump assemblies. Clumsy automation ${ }^{1}$ and poor interface design, ${ }^{2}$ which plague so many devices, are two examples. While these are potentially soluble problems, problems inherent in the physics of the technique seem intractable. Just how intractable, and how important, can be seen in the paper by Weiss et al. ${ }^{3}$ in this issue of the Journal. They studied syringe assemblies using precision methods that reveal what may well be the Achilles heel of this technique. Their study marks a point in the natural history of technology.

The experience with syringe pump assemblies, and with their discontents, follows an evolutionary process typical for clinical technology. Indeed, the natural history of medical devices of all types is surprisingly consistent. Problems with old technologies are a stimulus for development of new ones. Early in new technology evolution, around the time of introduction, a plethora of problems are identified. While some of these problems can be anticipated during design, most arise in the circumstances of use when characteristics of the devices, the context of use, and the users combine. These subtlety and heterogeneity of these combinations marks the "young" phase of technological evolution.

During this young phase, problems appear, one by one, and countermeasures are devised, tried, and evaluated. Debates about the value of the new technology $p s$ the old abound. Always there is an identifiable champion of the new, perhaps the inventor but more often a clinician or group of practitioners convinced that the benefits of overcoming the limitations of the old technology outweigh the problems and uncertainties that

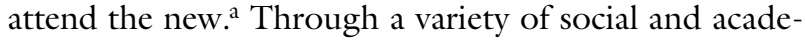
mic channels, appreciation of the problems and the countermeasures becomes widespread. Because the problems are new and the technology is young, the problems and countermeasures are explicitly attended to and discussed. Journal articles or, more often, letters to the editor, identify the problems and possible solutions and much thought is lavished on the assessment of strengths and weakness of this or that method or the appropriateness of this device or that one. Discovery of effective, easily applied countermeasures convert a problem from "hard" to "easy". Gradually, the countermeasures become ordinary practice, not seen as separate from the technology but a part of it and its use. What the problems are and how they are best handled stops being new and becomes settled territory and as new practitioners enter the field their introduction to the technology includes the countermeasures.

\footnotetext{
a Sociology of technology studies describe the social construction of artifacts. The thesis of this school of research is that artifacts are socially constructed rather than being the inevitable result of engineering forces. Blume ${ }^{4}$ describes this process for medical imaging equipment; for a larger context see Latour. ${ }^{5}$ The role of understanding technical aspects of failure in creating new design is described by Petroski. ${ }^{6}$
}

Address correspondence to: Dr. Richard I. Cook, Cognitive technologies Laboratory, Department of Anesthesia and Critical Care, University of Chicago, 5841 S. Maryland Ave., MC 4028, Chicago, IL, 60637 USA. Phone: 1+773-702-5336; Fax: 1+773-702-3535; E-mail: ri-cook@uchicago.edu 
With time, the application of countermeasures becomes a ritual practice ${ }^{7}$, that is, countermeasures are applied not because we recognize potential problems and apply specific countermeasures but rather because the regular use of the countermeasures is routine within the community of practice. Ritual is central to medical practice because it encodes the learning of the past in convenient ways; we know how things ought to be done and do them that way. This is not because we consciously review all the reasons for the countermeasures but because we (and others) have, over time, explored the territory and know how to travel through it safely and efficiently. Indeed, so much of clinical practice in highly technical fields like anesthesiology and intensive care is comprised of ritualized countermeasures that we identify expert practitioners partly by the ease with which they apply the panoply of countermeasures that make patient care safe. Failing to adhere to rituals is the mark of a novice and it arouses strong criticism from practitioners in the community.

As medical technologies mature, fewer new problems are identified and the applications of the technology become stereotypical and mundane. For a technology to be successful, nearly all of the problems must be "easy", i.e., closely matched with useful, easy to apply countermeasures. The development of the technology shifts towards refinement, often adding features (sometimes called "bells and whistles") that make the technology easier to use, more reliable, or more convenient. ${ }^{\mathrm{b}}$ But even late in the evolution of a technology, residual problems sometimes remain. These residual problems, the "hard" ones, are usually tied to deep features of the technology and the domain of practice, for example the physics that underlies the process in question. Significantly, when they are first encountered, whether a problem will turn out to be easy or hard is not clear.

Truly hard problems are never matched with countermeasures but this is not for want of trying. In fact, many countermeasures are proposed, attempted, and found wanting. It is only through exploration, failed attempts to devise counter measures, and efforts to discover the underlying sources of problems that we

\footnotetext{
${ }^{\mathrm{b}}$ A certain marker that a technology has reached this stage is its conversion from a distinct entity to a component, i.e., absorption into some larger purpose framework. The archetype is the pulse oximeter, once a stand-alone instrument and now almost exclusively just one part of some multiple function device. The uncertain future of young technologies keeps their incarnations discrete. Technologies that survive to maturity become candidates for the conversion to component status.
}

become convinced that this one is hard while that one is easy. Eventually, the hard problems describe a kind of boundary for the mature technology - beyond the edge of the boundary the technology simply doesn't work in a satisfactory way, e.g. "we don't use this device (or this technique, or this instrument) here because it doesn't work in this situation (with this sort of patient, with this condition, with these other instruments)." The incentive to develop new technologies comes in large part from these residual hard problems. Understanding what makes the residual problems hard becomes the focus of attention for engineers and designers as they work to create new technology.

The advent of this new technology marks the old age of its predecessor. As the new technology gains acceptance, the old one is used less and less, usually by older practitioners for whom the technology is familiar and comfortable. At the end, the old technology becomes simply a reference point located somewhere in the past and enshrined in the first chapters of textbooks where histories of the specialty are sketched. Its use (often a remarkable event in itself) becomes a pedagogical rather than clinical demonstration.

Syringe pump assemblies are an example of a mature clinical technology. As with other mature technologies, the many problems that can arise during the use of syringe pump assemblies are largely offset by effective countermeasures. For example, it is common practice to reserve a single intravenous line (or a single port of a multiple line catheter) for vasoactive drugs and to provide it with a "carrier" infusion running at a fixed rate. By isolating the infusion of vasoactive drugs from bulk fluids changes in the flow rate of the powerful drugs are minimized. By using the carrier solution, the effect of deadspace in the tubing "jungle" is minimized, making rapid titration of infusion rates possible. Evidence that this practice has become ritualized may be found in the sort of discussions that do not take place at the bedside. For example, when the ICU nurse says to the anesthesiologist preparing to take a patient to the operating room, "the pressors are running through the distal port of the triple lumen" neither party to the conversation asks why these infusions are segregated. Another example of effective countermeasure is power handling. Exhausted batteries can interrupt flow so practitioners take care not to unplug syringe pumps from the mains until just before transport to the operating room and to plug them in shortly after arrival. ${ }^{c}$

Maintaining a constant, small flow rate is the remaining hard problem for syringe assemblies. The sources of this problem now appear to be intractable because they arise not from features of the drive mech- 
anism but from the mechanical properties of the syringe and tubing system per se. Weiss et al., used gravimetric methods to examine the behaviour of syringes under clinically relevant conditions. Their data imply that syringe compliance per se is the source of changes in instantaneous infusion rates that accompany changes in the syringe height above (or below) the patient. The effects of even relatively small changes in height can result in either a period of no infusion (when the syringe is lowered) or a sudden bolus infusion (when the syringe is raised). The duration of the suspension or size of the bolus is proportional to the height change.

The importance of this technological phenomenon is greatest when infusion rates are low, the infused drug is concentrated, and the drug has a short half-life in circulation. If one could use low concentrations and high infusion rates the phenomenon would still be present but its consequences would be small. Indeed, in most situations, this countermeasure works and the problem is easy. But, for patients where tiny volumes matter, usually themselves tiny and frail, the problem is quite hard.

At first glance, there is an obvious countermeasure for the problem that Weiss et al. have quantified. It is to ensure that the height relationship between the patient and the syringe device never changes. Surely, in the wake of this paper, we will see a variety of approaches for accomplishing this end. Readers can easily envision rigid assemblies, tape measures and sliding clamps to hold things 'just so' for long periods. But none of these patchwork methods will address the other issues that underlie the physics of this phenomenon. Changes in venous back pressure, whether through mechanical ventilation, infusion of fluids, or mechanical obstruction will have the same effect as raising or lowering the syringe assembly. Unlike the height issue, where we can readily detect when the phenomenon is happening and even possibly gauge its scale, changes in back pressure are hidden from view. It is not just that the effects are unknown, it is that they are, in clinical practice, unknowable. The constant delivery of low flow rates is clearly a hard problem - and it is like-

\footnotetext{
${ }^{\mathrm{c}}$ And in so many other instances, experience with countermeasures shapes the development of the technology itself. Battery alarms, automatic power downs, and a host of other power budget features are derived from countermeasures and to point practitioners to them. The refinements of a technology over its lifetime are largely a matter of incorporating the countermeasures into the technology itself or making it easier for the practitioners to apply the countermeasures, for example by advising them when such application is needed.
}

ly to be a hard problem for every infusion technology currently available. Indeed, the alternative devices may well be worse offenders.

If there are no effective countermeasures, what can one do? Clearly, regulation of the relative height between syringe pump and patient is essential. Using smaller diameter syringes can help, although it creates its own problems. Care in avoiding situations that change the back pressure may help (the prototypical example being a multi-lumen catheter with one high rate infusion in parallel with the low rate one). But all these are weak techniques. They are either difficult to accomplish or only partly offset the phenomenon.

Progress on this problem is not likely to come from efforts to develop countermeasures. Hard problems are, after all, what is left over after the easy problems have been matched with countermeasures. At the end of technology's natural history, the few remaining hard problems prompt development of new technologies, not refinement of the old. While there are no good candidates in sight, the new technologies may be expected to have several characteristics. They will be expensive at first. They will seem cumbersome, awkward, and clumsy. Their use will seem justified only with those patients where the hard problems of the old technology really matter. They will have their own problems and limitations. Competition between candidates will be fierce. But with time the costs and clumsiness will be reduced. The time and effort spent to learn about the new technologies and their associated countermeasures will gradually make it easier to use them in most cases rather than just in those where they are indisputably needed. Eventually a single technology will gain a wide following. Once in the lead, its manufacturing costs will fall. As its use becomes routine, the application of its specific countermeasures will become ritual practice. And then the syringe pump assembly will become an object of historical interest, brought out to demonstrate to new practitioners that these things can actually be used, even though we don't use them any more. 


\section{Le montage des pom- pes à perfusion et l'évo- lution classique de la technologie clinique}

Le montage d'une pompe à perfusion - combinaison d'un mécanisme de commande, d'une seringue, d'une longueur de tube et d'un robinet à trois voies - apparaît clair, facile à comprendre et simple à utiliser. Ces montages sont utilisés pour offrir des perfusions continues en soins intensifs, perfusions qui peuvent se prolonger pendant de longues périodes qui incluent les déplacements vers la salle d'opération ou en provenance de cette salle. Les perfusions continues de vasopresseurs sont ajustées empiriquement pour atteindre un équilibre, souvent précaire, entre des forces physiologiques compétitives. La vitesse de perfusion précise est fréquemment le reflet d'un compromis soigneusement choisi entre des objectifs conflictuels. Une fois établie, une perfusion ne peut être interrompue sans conséquences graves.

Les praticiens d'expérience prennent soin d'éviter les manœuvres qui pourraient changer la vitesse d'écoulement des médicaments vasoactifs. Malgré tout, l'utilisation des montages de pompe à perfusion présente toujours des difficultés. Une automatisation lourde $^{1}$ et une conception d'interface médiocre, ${ }^{2}$ qui affectent tant d'appareils, en sont deux exemples. Même si ce sont des problèmes apparemment solubles, d'autres problèmes inhérents cette fois à la physique de cette technique semblent intraitables. C'est ce que démontrent Weiss et coll. ${ }^{3}$ dans leur article du présent numéro du Journal. Ils ont étudié des montages de pompes à perfusion en utilisant des méthodes précises qui révèlent ce qui pourrait être le talon d'Achille de la technique. Leur étude marque une étape dans l'évolution classique de la technologie.

L'expérience des montages de pompes à perfusion, et du mécontentement qu'ils provoquent, suit l'évolution typique de la technologie clinique. En effet, l'histoire des appareils médicaux de tout genre est d'une régularité surprenante. Les problèmes des anciennes technologies stimulent le développement de nouvelles. Une nouvelle technologie présente une foule de problèmes au moment de son introduction dans la pratique. On peut prévoir certaines difficultés, mais la plupart apparaissent dans des situations où se combi- nent les caractéristiques de l'appareil, le contexte d'utilisation et les utilisateurs. La subtilité et l'hétérogénéité de ces combinaisons sont la marque de la «jeunesse» de l'évolution d'une technologie.

Durant cette première phase, les problèmes apparaissent, un à un, et des contre-mesures sont suggérées, essayées et évaluées. De multiples débats ont cours opposant la nouvelle technologie à l'ancienne. Il se trouve toujours un défenseur reconnu de la nouvelle technologie, l'inventeur peut-être, mais le plus souvent un clinicien ou un groupe de praticiens convaincus que les bénéfices à retirer en surmontant les limites de l'ancienne technologie vont l'emporter sur les problèmes et les incertitudes qui accompagnent la nouvelle technologie. ${ }^{a}$ C'est par différentes voies sociales et académiques que l'évaluation des difficultés et des contre-mesures se répand. Comme les problèmes sont nouveaux et la technologie récente, les problèmes et les contre-mesures sont explicitement pris en compte et étudiés. Les articles de journaux scientifiques ou, le plus souvent, le courrier des lecteurs permettent d'identifier les problèmes et les solutions possibles. On discute beaucoup de l'évaluation des forces et des faiblesses de l'une ou l'autre méthode ou de l'utilité de l'un ou l'autre appareil. La découverte d'une contre-mesure efficace et facile à appliquer convertit un problème dit «difficile» en un problème «facile» à résoudre. Graduellement, les contremesures font partie de la pratique régulière et ne sont plus considérées à part de la technologie mais comme lui étant intégrée. Les problèmes ne sont plus nouveaux, ni les meilleures moyens de les régler. Cela devient un territoire établi et quand de nouveaux praticiens font leur entrée en pratique, leur introduction à la technologie comprend les contre-mesures.

Avec le temps, l'application des contre-mesures devient une pratique rituelle, ${ }^{7}$ c'est-à-dire que les contre-mesures sont appliquées non pas parce que nous reconnaissons les problèmes possibles et appliquons des contre-mesures spécifiques, mais plutôt parce que l'usage régulier des contre-mesures est une routine adoptée par tous les praticiens. Le rituel est central en pratique médical. Il encode le savoir du passé par des moyens commodes; nous savons comment les choses

\footnotetext{
a La sociologie des études sur la technologie décrit la construction sociale des artéfacts. La thèse de cette école de recherche veut que les artéfacts soient socialement construits plutôt que d'être le résultat inévitable des forces de l'ingénierie. Blume ${ }^{4}$ décrit cette évolution dans le cas de l'équipement en imagerie médicale; Latour présente un contexte élargi. ${ }^{5}$ Le rôle joué par la connaissance des aspects techniques de l'échec à créer de nouveaux modèles est décrit par Petroski. ${ }^{6}$
} 
doivent être faites et nous les faisons ainsi. Ce n'est pas que nous ayons consciemment revu toutes les raisons qui ont amené les contre-mesures, mais bien que nous, et d'autres, ayons exploré le territoire et, qu'avec le temps, sachions comment le traverser en toute sécurité et efficacité. En effet, une partie tellement importante de domaines hautement techniques comme l'anesthésiologie et les soins intensifs est constituée de contremesures ritualisées que nous pouvons identifier les praticiens experts par l'aisance, entre autres, avec laquelle ils appliquent la panoplie de solutions qui assurent la sécurité des soins au malade. Le défaut d'adopter les rites est la marque du novice et soulève une critique sévère de la part des praticiens réguliers.

À mesure que les jeunes technologies médicales acquièrent de la maturité, moins de problèmes se présentent et les applications de la technologie deviennent stéréotypées et banales. Pour qu'une technologie ait du succès, presque tous les problèmes doivent être «faciles» à résoudre, c'est-à-dire, étroitement assortis à des contre-mesures utiles et faciles à appliquer. Le développement de la technologie amène certains raffinements, souvent l'addition de caractéristiques qui rendent la technologie facile à utiliser, plus fiable ou plus pratique. ${ }^{b}$ Mais même à un stade avancé de l'évolution d'une technologie, des problèmes résiduels peuvent persister à l'occasion. Ces problèmes, «les difficiles», sont habituellement en lien avec des caractéristiques obscures de la technologie et du domaine de pratique, comme les principes de physique à l'origine du processus en question. Lorsqu'un problème se présente pour la première fois, nous ne savons pas clairement s'il était facile ou non à résoudre.

Les problèmes vraiment difficiles ne sont jamais assortis de contre-mesures, mais ce n'est pas faute d'avoir essayé. De fait, de nombreuses contre-mesures sont proposées, essayées et ne sont pas concluantes. Ce n'est que par l'exploration, l'échec des contre-mesures imaginées et les efforts pour découvrir la source des problèmes que nous en arrivons à la conviction qu'un problème est facile ou difficile. Enfin, les problèmes difficiles dessinent une sorte de frontière de la technologie à maturité - au-delà de la ligne de frontière, la tech-

\footnotetext{
${ }^{\mathrm{b}}$ Un indice certain de l'atteinte de ce stade est la conversion de la technologie qui passe du statut d'une entité distincte à celui de composante dans le cadre d'un plus grand projet. L'archétype en est l'oximètre pulsé, un instrument qui se suffisait à lui-même à ses débuts et qui, maintenant, fait presque exclusivement partie d'un dispositif à multiples fonctions. L'avenir incertain des jeunes technologies maintient leur utilisation discrète. Les technologies qui survivent jusqu’à leur maturité deviennent des candidates à la conversion au statut de composante.
}

nologie ne fonctionne tout simplement pas de manière satisfaisante; par exemple, «nous n'utilisons pas ce dispositif (ou cette technique ou cet instrument) ici parce qu'il ne fonctionne pas dans la situation actuelle (avec ce type de patient, dans ces conditions, avec ces instruments).» La motivation à développer de nouvelles technologies vient en grande partie de ces problèmes difficiles résiduels. La compréhension de ce qui rend les problèmes résiduels difficiles devient le centre des préoccupations des ingénieurs et concepteurs qui créent la nouvelle technologie.

L'avènement de cette nouvelle technologie marque le grand âge de celles qui l'ont précédée. À mesure que la nouvelle technologie est acceptée, l'ancienne est utilisée de moins en moins, habituellement par les praticiens âgés pour qui la technologie est familière et aisée. À la fin, l'ancienne technologie devient un simple point de référence localisé quelque part dans le passé et inséré dans les premiers chapitres des manuels où l'histoire de la spécialité est esquissée. Son utilisation, souvent un fait remarquable en lui-même, devient une démonstration pédagogique plutôt que clinique.

Le montage des pompes à perfusion est un exemple de technologie clinique à maturité. Comme avec d'autres technologies à ce stade, les nombreux problèmes qui peuvent survenir pendant l'utilisation d'assemblage de pompes à perfusion sont grandement compensés par des contre-mesures efficaces. Par exemple, on réserve fréquemment une seule voie intraveineuse, ou une seule ouverture d'un cathéter à multiples voies, pour administrer des médicaments vasoactifs au moyen d'une perfusion «vecteur» qui fonctionne à une vitesse déterminée. En isolant la perfusion de médicaments vasoactifs de la masse des liquides, on peut réduire les changements de la vitesse d'écoulement des médicaments puissants. L'utilisation de la solution vecteur permet de diminuer l'effet d'espace mort dans la tubulure et, par conséquent, de fixer rapidement les vitesses de perfusion. La preuve que cette pratique est devenue rituelle peut se trouver dans le fait qu'une discussion à ce sujet n'a pas lieu au lit du malade. Ainsi, lorsqu'une infirmière de l'USI dit à l'anesthésiologiste qui se prépare à recevoir un patient à la salle d'opération que «les vasopresseurs sont administrés par la lumière distale de l'appareil à trois voies», personne ne demandera pourquoi ces perfusions sont isolées. Un autre exemple de contre-mesure efficace concerne la manipulation de l'alimentation électrique. Des piles usées peuvent interrompre l'écoulement et les médecins prennent soin de débrancher les pompes de la source d'électricité, juste avant le transport vers la salle d'opération, et de les rebrancher le plus tôt possible.

Le maintien d'une vitesse d'écoulement constante et faible demeure un problème difficile dans le mon- 
tage des pompes à perfusion. Weiss et coll. ont utilisé des méthodes gravimétriques pour étudier le fonctionnement des seringues dans des conditions cliniques appropriées. Leurs données laissent croire que la compliance de la seringue est en soi la source des changements instantanés de vitesses de perfusion qui accompagnent les changements de position verticale de la seringue par rapport au patient. Même les effets de changements de hauteur relativement minimes peuvent entrainer une période sans perfusion, quand la seringue est abaissée, ou la perfusion soudaine d'un bolus, quand la seringue est haussée. La durée de la suspension ou le contenu des bolus sont proportionnels au changement de position verticale.

L'importance de ce phénomène technologique est plus grande lorsque les vitesses de perfusion sont basses, le médicament perfusé est concentré et le médicament présente une demi-vie de courte durée dans la circulation. Si on pouvait utiliser des concentrations faibles et de grandes vitesses de perfusion, le phénomène serait toujours présent mais ses conséquences moins importantes. En effet, dans la plupart des cas, cette contremesure fonctionne et le problème est facile à résoudre. Mais, chez les patients pour qui même des volumes très faibles ont de l'importance, eux-mêmes étant habituellement des êtres petits et frêles, la situation présente certainement un problème difficile.

Au premier abord, il existe une contre-mesure évidente au problème quantifié par Weiss et coll. C'est de s'assurer que la relation entre la position verticale de la seringue et le patient ne change jamais. À la suite de cet article, nous verrons qu'une diversité de réglages seront proposés à cette fin. Les lecteurs peuvent envisager des montages rigides, des rubans à mesurer et des clamps à glissière pour maintenir les choses «telles quelles» pendant de longues périodes. Toutefois, aucune de ces méthodes disparates ne permettra d'avoir accès aux autres composantes physiques à la base du phénomène. Les changements de contre-pression veineuse, que ce soit par ventilation mécanique, perfusion de liquides ou obstruction mécanique, auront le même effet que le fait de monter ou de baisser l'assemblage à perfusion. À la différence de la question de hauteur, où nous pouvons

\footnotetext{
c Et dans beaucoup d'autres cas, l'expérience des contremesures façonne l'évolution de la technologie elle-même. Des alarmes de pile, des mises hors tension automatiques et d'autres appareils aux caractéristiques liées à l'alimentation sont dérivés des contre-mesures et proposés à l'usage des praticiens. Le raffinement d'une technologie pendant sa durée de vie est surtout une question d'intégration des contre-mesures dans la technologie comme telle ou de facilitation de leur application par les praticiens, en les conseillant, entre autres, quand c'est nécessaire.
}

facilement détecter l'apparition du phénomène et même calibrer son échelle, celle des changements de contre-pression n'est pas visualisable. Ce n'est pas seulement que les effets soient inconnus, c'est qu'ils soient, en pratique, impossibles à découvrir. L'administration constante de perfusions à faibles débits est certainement un problème difficile - et le restera sans doute quelle que soit la technologie offerte présentement. Les appareils de remplacement pourraient vraisemblablement être plus dangereux.

S'il n'y a pas de contre-mesure efficace, que pouvons-nous faire? Une réglementation sur la hauteur relative entre la pompe à perfusion et le patient est absolument essentielle. L'usage de seringues à plus petits diamètres peut aider, quoiqu'il crée ses propres problèmes. Prendre soin d'éviter les situations qui modifient la contre-pression peut aider aussi, le prototype étant un cathéter à lumières multiples dont l'une sert à la perfusion à vitesse élevée et est mise en parallèle avec une perfusion à basse vitesse. Mais ce sont toutes des techniques peu fiables. Ou elles sont difficiles à réaliser, ou elles ne règlent qu'une partie du problème.

La résolution de ce problème ne viendra probablement pas des contre-mesures. Les problèmes difficiles sont, après tout, ce qui subsiste après que les problèmes faciles ont été résolus par des contre-mesures. À la fin de l'évolution normale d'une technologie, les quelques problèmes difficiles qui subsistent invitent à la mise au point de nouvelles technologies, non plus au raffinement des anciennes. Quoiqu'il n'y ait rien en vue, on peut s'attendre à ce que les nouvelles technologies présentent certaines caractéristiques. Elles seront chères au début. Elles paraîtront encombrantes, difficiles et grossières. Leur utilisation semblera justifiée auprès des patients chez qui les problèmes difficiles de l'ancienne technologie sont vraiment importants. Elles auront leurs problèmes et leurs limites propres. La compétition avec d'autres technologies sera acharnée. Mais avec le temps, le coût et la gaucherie seront réduits. Le temps et l'effort investis dans l'apprentissage des nouvelles technologies et leurs contre-mesures associées en rendront l'usage plus facile dans la plupart des cas plutôt que dans les seuls cas où ces technologies sont absolument nécessaires. À plus ou moins long terme, une seule technologie gagnera de nombreux partisans. Une fois en tête, son coût de fabrication chutera. Son utilisation devenant une routine, l'application de ses contremesures spécifiques deviendra une pratique rituelle. Et alors le montage des pompes à perfusion fera l'objet d'un intérêt historique, ressorti pour démontrer aux nouveaux praticiens que ces objets peuvent effectivement servir, même si nous ne les utilisons plus. 


\section{References}

1 Cook RI, Woods DD. Implications of automation surprises in aviation for the future of total intravenous anesthesia (TIVA). J Clin Anesth 1996; 8: 29S-37S.

2 Cook RI, Woods DD, Howie MB, Horrow JC, Gaba DM. Case 2-1992. Unintentional delivery of vasoactive drugs with an electromechanical infusion device. J Cardiothorac Vasc Anesth 1992; 6: 238-44.

3 Weiss M, Hug MI, Neff T, Fischer J. The effect of syringe size and infusion rate on zero-drug delivery time, aspiration volume and infusion bolus after vertical displacement of infusion pumps. Can J Anesth 2000; 47: 1031-35.

4 Blume SS. Insight and Industry: On the Dynamics of Technical Change in Medicine. Cambridge MA: MIT Press, 1992.

5 Latour B. Where are the missing masses? The sociology of a few mundane artifacts. In: Bijker WE, Law J (Eds.). Shaping Technology/Building Society. Cambridge MA: MIT Press, 1992: 225-58.

6 Petroski H. To Engineer is Human: The Role of Failure in Successful Design. NY: St. Martin's Press, 1992.

7 Cook RI, Woods DD. Adapting to new technology in the operating room. Hum Factors 1996; 38: 593-613. 